\title{
An Evaluation of the Administrative Reform Efforts in Turkey
}

\section{Assistant Professor Dr. Zuhal Önez Çetin}

\author{
Uşak University, Public Administration Department, Head of the Local Government Studies \\ zuhal.cetin@usak.edu.tr, zuhalonez@gmail.com
}

Doi:10.5901/mjss.2015.v6n6p11

\begin{abstract}
The administrative reform that is identified as the series of the measurements relating to the renewal and the development of the administration in a constant and systematic way went back to the 18th century in Turkey. By the establishment of the Turkish Republic, the solution of the problems of public administration and its development came to the political agenda. In that framework, one of the main objectives at the article is the analysis of the administrative reform efforts of the Republican period with categorizing it into four periods; such as administrative reform efforts before planned period, administrative reform efforts at planned period, administrative reform efforts at 1980s, and administrative reform efforts at the last period. Within the context of the study, the administrative reform concept is tried to be elaborated and a critical evaluation of the prepared Reports, Projects, and five-year development plans on the administrative reform is attempted to be made with demonstrating the strengths and weaknesses of those reform initiatives. Finally, as a concluding remark, it can be stated that a systematic and integrated approach could not be achieved at the administrative reform process in Turkey.
\end{abstract}

Keywords: Administrative Reform, Turkish Public Administration, Reform Efforts

\section{Introduction}

The entailment of reform arises from the difference between the existed situation of the administration and the expected situation. Thus, the reform stems from the belief that there is always a better option against the current status (Karaer, 1991: 43). In that context, the area of administrative reform problem that gains weight as a conscious effort is the state or, in other words, is the public administration. At that point, Şaylan (2012: 440) emphasized that all social systems are effective as long as they comply with the environmental change. Accordingly, the scholar also added that even if the public organization systems as a sub-social system that have a perfect structure, must monitor the change and take the measures appropriate to them. In that framework, the reform-making and re-organization efforts had come to the front side as a problem in almost every area for 200 years in Turkey. The last two hundred years of Turkish history passed with the continuous reform-making efforts in all areas of social life (Şaylan, 1973a: 15). At that point, Karaer (1987a: 25-26) determined that since Tanzimat (Reform) period, the issue of the improvement of the administration system had been a focal target, and during the Republican period with the transition to the planned period, intensive efforts had been launched in that field, and some re-organization efforts had been carried out. In that context, the scholar also emphasized that the overall objective of the administrative reform is to fulfillment of the functions of the public administration in a more effective, efficient, rapid, and economic manner in line with the national objectives. Furthermore, at the study, a historical research design is used with starting from the reform efforts before planned period to the administrative reform efforts of the last period (including $10^{\text {th }}$ five-year development plan), for examining the strengths and weaknesses of the previous and current reform initiatives. By the historical research method, the Republican Era administrative reform process has been examined in detail with categorizing it into four period; such as administrative reform efforts before planned period, administrative reform efforts at planned period, administrative reform efforts at 1980s, and administrative reform efforts at the last period.

Within the context of the article, the first objective is to set forth the determinations of the administrative reform in Turkey. Furthermore, the second objective of the study is the analysis of the administrative reports, projects and five-year development plans with indicating their main purposes, contexts, and their confronted problems at the application process. In this sense, the main drawbacks that hinder the success of the administrative reform efforts tried to be determined by the analysis of those related reports, projects, and plans. Lastly, at the conclusion part some recommendations had been put forth to shed light on a proper application of the administrative reform process in Turkey. 


\section{The Concept of Administrative Reform}

The administrative reform process has a long history in Turkey that went back to the $18^{\text {th }}$ century which is related with modernization efforts via the administrative reforms (Sözen, 2005: 198). Despite the long historical process of the administrative reform, the meaning and the scope of the terms of administrative reform, reorganization, re-structuring, the development of administration are not clarified in an explicit way and their synonym usages increased the confusions in many cases in Turkey (Altuntaş, 2007: 2). In that regard, Karaer (1991: 50) elaborated that "at the reports that were prepared for administrative reform in Turkey, there is not a consensus on the concept of administrative reform. In this context, while those reports envisaged a reform; it can be stated that they do not define what the reform is". At that point, it is worth to mention the definition of reform. Specifically, three important features are critical in the determination of reform such as; reform is closely linked to the social change; reform as a principle describes the radical changes; the target of the reform is to make the related administration more efficient and effective (Karaer, 1991: 48).

Although, there has no consensus on the definition of the administrative reform, Sürgit (1972: 10) designated the concept as "the all efforts that having the target of reaching of the administration to a scheme that can assist to fulfill the national targets of administration, ensure the provision of services in a rapid, cost-saving, efficient and qualified manner, and provide the possibility to the administration to perform its works on such a scheme". The scholar emphasized the administrative reform as a factor of the social change and clarified the objective of the reform as the 'administration modernization' (Sürgit, 1972: 19). In that framework, 'Administrative Reform Advisory Board' determined the administrative reform as the all regulations having the nature of short-long term, temporary and permanent, having the target to correct the failures and deficiencies at the objectives, duties, the division of tasks, the organizational structure, personnel system, resources and their usage formations, methods, communication and public relations system of the public institutions (Sürgit, 1972: 7; İdari Reform Danışma Kurulu Raporu, 1972: 7). In this scope, another influential scholar, Gencay Şaylan (1973a: 17) described the administrative reform as the alternative situation that emerged in the upper social system and institution due to the changes at the sub-systems. At that determination, the administrative reform is defined as the conscious and planned change of public institutions, the necessities that emerged in the administrative formation, and the relationship and behavior in parallel with changes at the social formation (Şaylan, 2003: 423). According to that related scholar, the administrative reform is not the initiator or the driving force/ engine of the social progress and development. In other words, at the discussion of the development, the administrative reform has a secondary importance (Şaylan, 1973b: 504-505). It is seen that reform and administrative reform have been identified with different determinations by various scholars of administration in Turkey.

\section{Republican Period Administrative Reform and Re-Structuring Efforts}

\subsection{Reform Efforts before Planned Period:}

By the establishment of the Turkish Republic, the solution of the problems of public administration and its development came to the political agenda. The Republican Period took over the administrative legacy of the Ottoman Empire. At the first years of the Republican period, there was a rapid legalization and rationalization process. At that context, the removing the legal and administrative dichotomy, improving the existing system, the establishing new institutions, and initiating efforts on the transformation of the system themes gained priority (Tutum, 1994: 66). The period before the 1960s formed the intellectual and theoretical phase of re-structuring public administration initiatives. In this regard, there are two distinguishing feature of that term; firstly, the conducted researches, projects, and reports were demanded by the government; secondly, the researches made by the foreign institution, organization, and experts (Kalağan, 2010: 67-68). It is worth noting that, II World War (II WW) marked the beginning of a new social formation in Turkey. At this new structure, changes were occurred in the functions that had been undertaken by the state according to the new social and political relationship patterns. However, while that related term is critical for the administrative reform in Turkey, numerous studies had been conducted concerning the administrative reform since the 1930s, and several reports had been prepared on this issue in Turkey (Tatar, 2006: 21). By 1933 onwards, lots of research and study had been made in relevant with the administrative reform, and various reports had been prepared on that dimension. The first of them was the Report titled 'An Examination of Turkey in Economic Terms' that was submitted to the government by a group formed by American experts (Al, 2008: 21). That Report was encompassing the administrative problems in Turkey, and it was published as three books (Tortop et al., 1993: 205-206). In 1947, it was observed that lots of commissions were formed for the examination of the precautions that provide efficiency and rationality in the state agency by the request of the prime minister. In 1948, various government departments and inspection boards of the ministries submitted reports in 
relevant with administrative reform (the improvement of administration and the administrative methods) by the request of the prime minister (Sürgit, 1972: 66; Karaer, 1987a: 27).

At that framework, one of the first scientific studies to improve public administration is the Neumark Report in Turkey. Dr. F. Neumark from the Istanbul University, conducted a study in 1949 and submitted the report titled 'The Principles of Rational Work within the Central Government' to the prime ministry by the request of the Turkish Government of the day (Sürgit, 1972; Mıhçıoğlu, 2003: 91; Tutum, 1994: 84-85). According to the Neumark Report, a part of the rational working principles at the public institutions and organizations encompasses the issue of the personnel or personnel policy. It was envisaged that the problems in related with the number of the civil servants and their quality prevented the rational working of the public institutions (Şaylan, 2000: 109). At that context, Sevinç (2014: 733) pointed out that "while Neumark Report was a pioneer scientific study in the field of administrative reform; that Report mainly pointed out the dimension of the personnel management rather than taking the administrative reform as a whole". Furthermore, the Barker Report was published in 1951 that was prepared by a committee consisting of 13 members. That related Report was financed jointly by World Bank (WB) and government. The objective of the Report determined as 'making an examination on the Turkish economy and submitting of the recommendations of the WB to the Turkish government on the long-term policies' (Güven, 1998: 107). Besides, the Report also gave emphasis on personnel management with declaring the necessity of the re-organization of public personnel management in addition to the recommendations towards the social and economic development (Demirci, 2010: 155). At that context, Aykaç (2003: 162163) clarified that "at the Barker Report, it is obvious that rather than initiating a detailed analysis; some recommendations were preferred to be made in which the committee envisaged those areas as urgent and compulsory".

By the same token, in 1951, two experts James W. Martin and Frank A. Cush prepared a Report titled 'Martin and Cush Report' concerning the examination of the organization and working principles of the Ministry of Interior and personnel problems, and submitted that Report to the Ministry of Interior. At that study, the necessity of the establishment of a central personnel department was recommended that its jurisdiction field encompassing all ministries, annexed budget institution, state-owned enterprises, and local governments (Kalağan, 2010: 69; Sürgit, 1972: 70; Karaer, 1987a: 28). Besides, those issues were listed among the proposals in related with the solution of the personnel problems such as; equitable and just treatment of the civil servants, the enactment of a law encompassing all public services, the establishment and maintenance of a just wage system, the creation of central examination system at the recruitment process, the re-organization of the public institutions, and the formation of a personnel record system (Şaylan, 2000: 110). Finally, Kara (2006: 156-157) emphasized that "these related reports that put forth the establishment of a central personnel department as an essential need paved the way for acceleration of the establishment of the State Personnel Department (SPD)".

Furthermore, the Swiss professor Leimgruber in 1951, with the request of the government, made an examination concerning the organization and personnel issues, and submitted the report to the government on 25/12/1952. The Report dwelt upon the legal status of the central government and municipality personnel, the establishment of a central personnel department, the reduction of the number of the civil servants, wage regime, working hours, personnel cadres, and the classification of the personnel (Kantarcıoğlu, 1977: 24; IGB, 1994: 34; Gül \&Aktel, 2004: 82; Şaylan, 2000: 110). Apart from the reports as mentioned above, various studies had been conducted by TODAIE (Turkey and Middle East Public Administration Institute) that launched to operate in 1953. However, the reform efforts from the establishment of the Turkish Republic to the 1960s failed to achieve the desired success. In that regard, the main reasons can be listed as follows (Uçar \&Karakaya, 2014: 157; TODAIE, 1972: 19);

\begin{abstract}
"serious researches were not implemented to reveal the nature and scope of the task of the administrative reform and to put forth the organizations that perform these tasks; at that period those reform attempts had been carried in the light of the individual recommendations and information; the focusing point was not the provision of the skilled personnel appropriate with the services which is the most important element of an organization; active public support was ignored at reaching the success at the administrative reform efforts".
\end{abstract}

Moreover, Karaer (1987a: 27) also clarified that "until the 1960s, the reports were prepared by the foreign experts and international institutions with the mandate of the period's governments for making the necessary arrangements in public administration". Those reports had been criticized for their carrying of a subjective nature by dwelling upon the personal observations and recommendations and not establishing a balance between the existing administrative formation, and changing social and economic structure (Ergun, 2004: 50). Moreover, 'Administrative Advisory Board' also added that most of the research studies dwelt only on individual ministries or other administrative departments, and an appropriate environment for reform was not created (İari Reform Danışma Kurulu Raporu, 1972: 19). At that point, 
Karaer (1987a: 27) emphasized that "Turkish public administration failed to be reviewed in a complete and systematic way due to the insufficiency of the number of the experts; and limited number of researches had been made at the central and institutional level". Sürgit (1972: 163, 1980: 67) also clarified that "those studies constituted a particular stage in improving the administration; however, they remained as the form of recommendations that were applied in the solution of the problems encountered during the implementation of the services". It is noticeable that those studies mostly remained as unsystematic and irregular efforts. Despite this situation, the results in related with the improving of the administration before planned period are declared as noteworthy in terms of their cumulative effects. Again, the adoption of the administrative reform obligation in the last years of that period and taking serious steps for the provision of the necessary precautions on that issue are emphasized as the vital factors having an impact on the subsequent period (Sürgit, 1972: 46).

\subsection{Reform Efforts at Planned Period:}

The most conscious efforts in related with the re-organization of administration launched during the planned period. Thus, since 1963, the enactment of the five-year development plans had affected the arrangements that will be made in the economic field and also in the administrative field. By the same token, the administrative reform efforts launched to be conducted within the framework of the development plans, the administrative reforms came to the front side at the plans and annual programs; and the administrative plans paid the attention towards the re-organization of administration as a whole (Gül \&Aktel, 2004: 82; Keleş, 2006: 443). At the first Five-Year Development Plan (FYDP), a new idea was articulated such as the bringing the administration to a level that can meet the necessities of a developing economy in a rational and rapid manner with the central and local governments. At the second FYDP, the purpose was expanded and the main objective of the re-organization of the public institutions and organizations was identified as reaching the determined economic and social targets with the application of the plan (Yalçındağ, 1971: 26).

The planned period was a turning point in Turkey in terms of the improvement of the administrative system. In that regard, Karaer (1987a: 29) clarified that "unlike the 1940s and 1950s, the re-structuring efforts were carried out by the Turkish experts; and the objectives of identifying the purpose, scope, and meaning of the administrative reform and the organization that fulfill them, and making the necessary examination towards them coincide with that period". In this sense, the efforts towards the administrative reform at the planned period can be listed 'Preliminary Report on Administrative Reform and Reorganization' (1961), 'MEHTAP', 'Administrative Reform Advisory Board Report' (1971). At the following sub-items of the article, those Reports mentioned above have been examined in detail.

\subsubsection{Preliminary Report on Administrative Reform and Reorganization (1961):}

This report prepared in 1961, on the request of the SPO and National Unity Committee by TODAIE. The Report examined the reform fields in two parts; such as organization and working methods, and personnel problems. At the Report, in the relevant section with the personnel, it was determined that the administrative problems were stemmed from personnel. Besides, at the general principles part of the report; it was expressed that the reform process takes a longterm period that entails sustainability (TODAIE, 1965: 8-13).

The Report examined the fundamental issues that put forth by the theme of organization with the major experiences in foreign countries and in the light of the Turkish administrative history. At the Report, it is also expressed that the document is only a preliminary report that invites the relevant people to think about some general suggestions (TODAIE, 1965: 3). In the Preliminary Report, it is highlighted that, the Report has two targets; firstly, serving to reach a realist approach on the nature of the administrative reform and re-organization; secondly, giving an idea concerning the fields of the administrative reform initiated in Turkey and the mechanism to perform the administrative reform (TODAIE, 1965: 5).

The Report consists of two main parts; at the first part titled general issues in relevant with the administrative reform and reorganization; the reasons that lead to the emergence of the administrative reform necessity, the mechanism to fulfill the administrative reform and re-organization, the theoretical themes had been addressed, and some general principles were indicated persistent with the administrative reform. In the second part, a concise evaluation was made about Turkey, and some recommendations had been developed for the administrative reform efforts (Coşkun, 2005: 18). In that framework, the administrative reform efforts examined that were made after II WW, some information was given in relevant with the existing administrative reform institutions, suggestions were made concerning the mechanism that carry out the administrative reform in a comprehensive vision. At the Report, TODAIE, SPO, and the SPD are highlighted as the institutions to carry out administrative reform efforts; besides, the establishment of an 'Administrative Reform 
Committee' proposed to guide the reform efforts at the central level (Coşkun, 2005: 18; TODAIE, 1965: 17). Finally, the conclusion of that Report was the basis of the 1962 Year Program Draft's section on 'the long-term reorganization precautions' (Sürgit, 1972: 84).

\subsubsection{The Central Government Organization Research Project (MEHTAP):}

One of the most influential administrative reform efforts at the planned period was the Central Government Organization Research Project (MEHTAP) prepared in 1964 that put forth recommendations persistent with the organization of the central government for making the change at the administration for reaching a convenient structure to realize rapid economic development (Sürgit, 1972: 86-87; Keleş, 2006: 444). At that point, Aslaner (2006: 52-52) emphasized that "the Report was mostly seen as the one of the first broad-scale research on Turkish administration by the Turkish experts. It was a starting point for the administrative re-organization efforts owing to the value of its recommendations". In that scope, the primary objectives pursued at that Report pointed out as follows (Sürgit, 1972: 86-87; Karaer, 1987a: 31; Sürgit, 1968: 7);

"to prepare a solid foundation for the implementation of the precautions involving the target of a more rational organization and procedure, a more systematic planning and coordination, a more effective financial control and a better functioning of personnel system via the appropriate distribution of the central government responsibilities; to shed light on the studies concerning the development of the internal organization and procedures of the ministries and agencies, and to make recommendations in relevant with the institution that take over the administrative development responsibility".

In that scope, MEHTAP Report expressed the main reasons that caused administrative problems as the financial insufficiency of the administration, personnel failures, organizational disorders, red-tape, and poorly regulated centralization (Şaylan, 1973b: 542; MEHTAP, 1966: 403-406; Akın, 2000: 82; Sürgit, 1972: 88). At the last part of the Report, it is recommended to examine the distribution of responsibility between central government and local governments; to search the authorities, resources and organizations of local governments. At that point, Aslaner (2006: 51-53) also declared that "at the Report, it is also pointed out that the administration should be revised to adapt the changing conditions and necessities".

Within the framework of MEHTAP Report, Aktan (1989: 160) clarified that "legal arrangements were proposed concerning personnel issues; however those recommendations could not find the possibility of implementation". Likewise, it was also declared that the proposals on the development of administration and the distribution of responsibilities had not been applied for years. At the study conducted after ten years revealed this fact dramatically (Dinçer \&Ersoy, 1974a). Consequently, according to Dinçer and Ersoy (1974a; 1974b: 73-74), "the Report brings robust diagnoses to the problems of Turkish administration and it puts forward guiding suggestion on how an organization can be entailed for a contemporary state, and how a personnel policy can be followed, and the Report has a feature of long-term impact on Turkish administration history". However, as a result of this related research, it is also emphasized that the reform developed in a headless, disorganized, and unsystematic way, and the reform is not evaluated with systems approach, the coordination is not provided in the application process. Finally, Akın (1998: 96) also declared that "it is observed that the recommendations of the report viewed positively, but there was a low implementation level".

\subsubsection{Administrative Reform Advisory Board Report:}

By Decree No. $7 / 2527$ on 29/05/1971, according to the government program, an 'Advisory Committee' formed to determine the general direction and the strategy of the re-organization of the administration, and this Committee began their tasks on June 18, 1971 (Sürgit, 1972: 149). The working principles of the 'Advisory Committee' can be listed as (Idari Reform Danışma Kurulu Raporu, 1972: 1-2); "to determine the general direction and strategy of the re-organization of the administration, to put forth the form of the organization to carry out the re-organization, to identify areas and the priorities of re-organization and, to evaluate the administrative reform efforts up to that time and connecting them to the application program". The Report covers the ways and the organization at the administrative re-organization, the principles adopted at the re-organization, and the themes of the concinnity with the state-owned enterprises (İdari Reform Danışma Kurulu Raporu, 1972: 1-3).

The Advisory Committee determined the name of their studies as 'Determination of the General Direction and Strategy of the Re-organization of Administration' and the studies of the project carried out between July and September $14^{\text {th }} 1971$ with facilitating the all possibilities of TODAIE and also the assistance and collaboration of the various public 
institutions (item 14). In the Project, forty expert, six assistant specialist, and ten administrative staff took office from TODAIE, and various ministries and institutions (İdari Reform Danışma Kurulu Raporu, 1972: 3-4). The studies of the project resulted in the preparation of a general Report on October 1971, and the Administrative Reform Advisory Committee was distributed after submitting the report to the government on November 10, 1971 (Sürgit, 1972: 158). In the result of the study, the Report titled 'The Re-organization of the Administration Principles and Recommendations' published and recommendations were made to determine the general direction and strategy of the re-organization of the state according to the government program. At that point, Aktel and Memişoğlu (2005: 28-29) clarified that "it is noticeable that, the Advisory Committee did not conduct a new study, only made an evaluation of the previous studies". In that framework, Yaşamış (2001: 24) also emphasized that "while that Report was different from MEHTAP in terms of the administrative efficiency and effectiveness, it did not pass beyond a revision of the MEHTAP Report owing to its context. The Report only provided formal recommendations and preferred to evaluate the problems in a superficial way, and focused on the revision of the functions and responsibilities of the ministries that are tied to central government".

\subsection{Reform Efforts after 1980s:}

When coming to the 1980s, Turkey's administrative system is criticized for lacking of the capacity of renewal and flexibility in accordance with the social and economic developments in its organization and functioning that are far from rapidness and efficiency. Besides, it was not possible to achieve the targeted results with the development plans due to not the provision of public services in a qualified and efficient way (Karaer, 1987b: 29). In this regard, Karaer (1987b: 36-38) clarified that "at the period after 12 September 1980 to the end of the 1984; drastic re-organization efforts had been realized in the field of public administration. The National Security Council that took over the administrative control focused on primarily the public administration and re-organization of public administration". At the government program at the prime ministry period of Bülent Ulus; the public administration had been drawn with those themes as follows; excessive centralization, imbalance in the distribution of duties and responsibilities, over-employment, idle capacity, unnecessary formalities, and red-tape disease. A commission was established for making an 'Operations Research' (Yön Eylem Araştırması) for the problems of the public personnel system; the studies of the commission put forth the reasons of public personnel problems as the employment policy implemented by the state, and the instability at personnel regime, and the problems at public administration (Karaer, 1987b: 36-38).

Afterward, according to those determined problems, 'Public Employment Policy', 'Personnel Regime' and 'Reorganization of Public Administration' commissions were established. In that context, the report of the 'Re-organization of Public Administration' commission was declared as an influential commission due to its dealing with the short-comings and the solutions towards the problems of public administration. In the report, instead of using the concepts of administrative reform or re-organization, the development of administration concept was used; in addition to that the establishment of a responsible center at the re-structuring process was determined like the previous reports (Karaer, 1987b: 36-38). According to Karaer (1987b: 53), although drastic researches were not made on the organization which had been re-organized; concrete and coherent re-organization efforts were initiated with the cooperation of the relevant administrators in the fields of public administration.

\subsubsection{KAYA Project (Public Administration Research Project):}

The government that came to the power by the 1983 general elections addressed the gathering of the services having similar quality in a single organization and made the application of the reduction of the number of the ministries for the realization of the target of providing the public services more quickly and efficiently. Thus, it was emphasized that the revision of the public administration before the sixth FYDP plan became a necessity (Ergun, 1991: 12). For this purpose, a research had been requested to be done by TODAIE from SPO in 1988 according to shed light on the sixth FYDP and annual program application for the development and re-organization of public administration, to examine to what extent the studies made up to that time reflected to the application, to reveal the bottlenecks and failures of studies and applications and, and to clarify the precautions to be taken related to them. The issue was tackled with by TODAIE as 'Public Administration Research Project' (Ergun \&Polatoğlu, 1992: 21). The KAYA Project started in 1988 and ended in 1991. The Project announced to the public in June 1991, with the title of 'General Report of the Public Administration Research' and same year published by TODAIE with the same name (Aslaner, 2006: 60). In that context, the objectives of the KAYA Project can be listed as follows (Ergun \&Polatoğlu, 1992: 21; TODAIE, 1991: 3);

"reaching of the central government and local governments to a standard that they can provide effective, rapid, 
economic, and qualified public services; ensuring the compliance of the public administration to the developing contemporary conditions, determining the problems, failures at the purposes of the public administrations, at their power and responsibilities, distribution, organizational structure, personnel systems, resources, at their resource usage formation and methods, at their regulations, communication and public relations system".

The general scope of the Project is composed of general and annexed budget institutions that make up the central government, their provincial unit, local governments, and other public institutions (TODAIE, 1991: 3). In that scope, according to Geray (1993: 10), KAYA Report has several important features. In this regard, the first influential peculiarity is its tackling with the different areas of public administration (the central government, provincial unit, and local governments) together in a coherent way. Secondly, the necessary connections tried to be set up among the local governments, and also between the local governments and central government. Thirdly, it is critical that the efficiency, effectiveness, and democratization did not use as opposing concepts contradict each other at the KAYA Report. As the concluding remarks concerning the Project, it can be stated that KAYA was a comprehensive Project in terms of its targets and the subjects. In that framework, Coşkun (2003: 213) clarified that "while MEHTAP Project affects the other subsequent studies, KAYA Project's effects continue to our present time. The recommended topics cannot be realized in a systematic and comprehensive way. However, some of the recommendations of that Project realized in time". At that point Uçar and Karakaya (2014: 159) pointed out that the Reports that were prepared from 1960 to 1980 tackled the issue of re-organization of the public administration at the organizational researches with the classical approach. Those scholars also added that the envisaged changes stayed in the level of recommendation. In that framework, Aykaç (2003: 68) determined that "the conclusions and determinations of the KAYA Report were not much different from the previous studies".

\subsection{Administrative Reform Efforts at the Last Period:}

After the KAYA Project, there is not a wide-range re-structuring effort in Turkey. At the fifth FYDP (1985 - 1989) which was in force at the starting period of the KAYA Project and also at the sixth FYDP (1990-1994) which was in force at the end of the Project; the re-structuring argument was still on the agenda. At those plans, the term of 'public administration improvement' was preferred (Coşkun, 2005: 35).

In that context V. FYDP (1985-1989) those listed principles and policies were determined at the improvement of the public administration such as the simplifying the bureaucratic procedures, enabling the human-resource planning compatible with the functions of the organizations, determining the limits of the task and the responsibility, delegating the authority, improving the personnel system, re-defining the relations between the central government and local government with concerning the principle of unity in the service provision with based on the distribution of public services in an appropriate and effective way, and preventing the resource waste, making organizational and administrative researches, taking measures to provide the economic, qualified, and rapid service provision (Coşkun, 2005: 35; DPT, 1985: 173).

Besides, at the VI. FYDP (1990-1994) those listed principles and policies were determined persistent with the administrative reform such as; basing on scientific research, adhering to the principles of effectiveness and efficiency, taking measures to increase the efficiency, and giving attention to the efforts concerning the increasing of performance, developing the modern administration systems for the provision of the public services in a rapid, qualified, and economic way, and providing services in a qualified and economic manner, enabling and developing a rational personnel policy and a wage system compatible with the task and the responsibility, simplifying administrative procedures and processes at the government-citizens relations, and preparing a guidebook in related with those procedures (DPT, 1990: 360). By the same token, VII. FYDP (1996 - 2000) gathered the targets in relevant with the re-structuring of public administration under the title of the 'Increasing Efficiency in Public Services Project and Ensuring Wage Justice in the Public Sector'. At the plan, it was pointed out that the role of the state would be redefined within the framework of the globalization and integration policies and the public institutions should reach to organizational formations that compatible with their responsibilities. At that dimension, it was emphasized that the public services should be re-evaluated; and an approach should be settled that concerning the provision of the compliance with the task and the organization, the augmentation of the service efficiency, transparency, the employment of the required and capable personnel, the provision of the wage justice, participation, and citizen-oriented management approach' (DPT, 1996: 118).

At the VIII. FYDP (2001-2005), the issue of re-structuring public administration is discussed in the $9^{\text {th }}$ section under the title of the 'Improving the Efficiency at Public Services'. At this plan, the re-definition of the role of the state was still on the political agenda. At the plan, it was highlighted that there is a need for integrated, radical, and permanent change that 
encompassing the human resource, administrative principles, and functioning of the public administration. In that context, the recovery of the deficiencies and shortcomings at the targets, tasks, the division of tasks, organizational structure, personnel system, resource and their usage formation, public relations system of the public institutions constitute the priority agenda. At that plan, the main objectives at the improvement of the public administration and re-structuring can be expressed as follows (DPT, 2001: 191);

- The creation of a public administration structure and functioning that considers the change and development, democratic government, and social justice.

- The settling of the methods in the public administration that based on qualified and rapid service provision.

At that plan, it was pointed out that at the re-structuring of the public administration; those basic issues are listed as essential themes; the re-evaluation of the public services, the provision of balance between the task and organization, the improvement of the service effectiveness, the provision of qualified services based on the citizens' demands, the employment of qualified and required number of staff, participation, and a citizen-oriented management approach (Şaylan, 2000: 4). At the IX. FYDP covering the period between 2007-2013, it was clarified that the globalization that is rapidly growing and spreading via the information and communication technologies affected the countries' economic and social developments (DPT, 2007). As a result of that, it was expressed that significant changes occurred not only at the organizational formation but also at the service production formations (Acar \&Gül, 2007: 2). At the IX. FYDP period, one of the development axes is determined as the increase in quality and effectiveness at public services to maintain the economic growth and a stable social development and to realize the plan vision (DPT, 2007: 1-2). Under that target, those sub-themes have been listed such as rationalizing power and responsibility among institutions, increasing policymaking and implementation capacity, developing the human-resource at public sector, disseminating and enabling egovernment applications, improving the justice system, and enabling the security services (DPT, 2007: 2-4). Lastly, at the X. FYDP (2014-2018), it was elaborated that influential developments provided for the wide usage of information and communication technologies for the effective and efficient provision of the public services with the rise in the level of efficiency in economy and competition power (Kalkınma Bakanlığı, 2014: 23). In addition to that, it was put forward that some new ministries set up and some of them abolished with the redefinition of the responsibility and authority distribution among ministries for ensuring the economic, efficient, and effective functioning of the public services. The transition to the strategic management has been extended which is adopted as a fundamental tool to ensure the policy development, programming; to strengthen budget capacity, and to provide accountability and financial transparency in public administration. Furthermore, it was pointed out that Ombudsman institution was established for strengthening the accountability, and the control area of the Court of Auditors extended that encompassing the whole public resources (Kalkınma Bakanlığı, 2014: 24).

Consequently, Acar and Sevinç (2005: 33) emphasized that "the public administration system was not fitted with the administration re-organization efforts and it left to the governments' initiatives that came to the power and led to lots of confusion; the determined objectives at the development plans failed to reach the required level". Besides, $\operatorname{Ar}(1983: 76)$ also added that "at the five-year development plans, the principles and suggestions have been made for improving the personnel system, increasing the service efficiency, transparency, human resource, simplifying the bureaucratic procedures at administrative systems issues for effective and efficient functioning of the public administration; however, it is quite difficult to say that those principles and proposals were realized".

\section{Conclusion}

The administrative reform is not a newly emerged process in Turkey; it went back to the modernization efforts in the $18^{\text {th }}$ century. However, the meaning and the context of the administrative reform has not an explicit usage (Tutum, 2012: 471472). At the Republican period, the period covering before the 1960s mostly determined with the reports demanded by government and made by the foreign institutions. In that regard, the most significant reform efforts before the planned period can be listed as the Barker Report, the Neumark Report, the Martin and Cush Report, and the Leimgruber Report. Those reform efforts which are noteworthy for the subsequent period reform initiatives could not bring the expected success. Furthermore, the most conscious reform efforts that conducted within the context of the development plans started at the planned period. In this context, the efforts towards the administrative reform at the planned period can be listed 'Preliminary Report on Administrative Reform and Reorganization' (1961), 'MEHTAP', 'Administrative Reform Advisory Board Report' (1971). The proposals that have been developed for the administrative reform at those Reports also have a positive impact on the following initiatives, but most of the recommendations could not achieve the possibility of implementation; they have been applied many years later. In that context, at the period after 12 September 1980 to the end of the 1984, many administrative reform efforts had been realized in the field of public administration. Besides, the 
KAYA project was influential that having those objectives such as; providing effective, rapid, economic, and qualified public services; ensuring the compliance of the public administration to the developing contemporary conditions, determining the problems, failures at the purposes of the public administrations, at their power and responsibilities, distribution, organizational structure, personnel systems, resources, at their resource usage formation and methods, at their regulations, communication and public relations system; however, it was also emphasized that the recommended objectives cannot be realized in a systematic and comprehensive way (Ergun \&Polatoğlu, 1992: 21; Coşkun, 2003: 213). Besides, at the following five-year development plans, lots of proposals have been made for providing efficient public service, transparency, employing qualified personnel, providing wage justice, citizen-oriented management approach, increasing policy-making and implementation capacity, developing the human-resource at public sector, disseminating and enabling e-government applications for a well functioning of the public administration. However, it can be stated that most of principles and proposals could not achieve the possibility of realization.

At that point, Administrative Reform Advisory Boards' recommendations are considerable at reaching a good functioning reform process, it was determined that the results of the existed studies should put into practice instead of making new research at the administrative reform studies; the institutions which are liable from the administrative reform should be strengthened. In Turkey, it is observed that before the implementation of the proposed recommendations, a new project was started in related with the administrative reform. The administrative reform process entails a long period for taking the expected results; for this reason the governments that came to the power should sustain the previous reform initiatives that put into practice before them. At the other side, there are also problems about the responsible administrative unit liable from the administrative reform process, concerning its organization, coordination and monitoring at the continuation of the reform initiatives. There is a need for an organization at the management of administrative reform; lots of institutions were assigned for the reform process, but those institutions mostly could not reach the required possibilities at the achievement of the good results. Likewise, the administrative reform process should be conducted in a systematic way with a holistic approach and a strategy that encompassing the all related groups and actors to the process such as NGOs, academic institutions, public, private, and professional organizations. Active public support should not be ignored at reaching the success in the administrative reform efforts. At that framework, the entailed enlightenment process concerning process, strategy, way, target, phases, and methods of the administrative reform should be realized to all related institutions. Lastly, the goal of the administrative reform and its strategy should be set around a scientific effort; and the objectives should be realistic, clear, applicable and appropriate with the socioeconomic, political, and environmental structure of Turkey.

\section{References}

Acar, A. \&Sevinç, I. (2005). 1980 sonrası Türk kamu yönetiminin merkez örgütünde yapılan reform çalışmaları (The reform efforts in the central organization of the Turkish public administration after 1980), Selçuk Üniversitesi Sosyal Bilimler Enstitüsü Dergisi, pp.1937.

Acar, İ. A. \&Gül, H. (2007). 1980 sonrasında kamusal mal ve hizmet sunumunda yaşanan dönüşüm (The transformation at the provision of the public good and services after 1980), 22. Maliye Sempozyumu Bildirileri (22 $2^{\text {th }}$ Finance Symposium Proceedings), 9-13 Mayıs. Süleyman Demirel Üniversitesi İktisadi ve İari Bilimler Fakültesi Maliye Bölümü, Antalya, pp.254-282.

Akın, C., (1998). Kamu yönetimini yeniden düzenleme intiyacı (The necessity to reorganize public administration), Türk Idare Dergisi, Year: 70, No: 419, pp. 89-100.

Akın, C. (2000). Kamu yönetimimizde yeniden düzenleme çalışmaları ve denetim sistemimiz (The reorganization of our public administration and audit system), Türk Idare Dergisi, Year: 72, No: 427, pp. 77-108.

Aktan, T. (1989). Kamu idaresi (Public administration), Bursa: Uludağ Üniversitesi Gelişsirme Vakfı (Uludağ University Development Foundation).

Aktel, M. \&Memişoğlu, D. (2005). Yerel yönetim reformlarının başarısızlık nedenleri (The reasons for the failure of the local government reforms), (Eds.) H. Özgür and M. Kösecik, Yerel Yönetimler Üzerine Güncel Yazılar-I (The Essays on Local Governments-I), Ankara: Nobel Publishing.

Al, H. (2008). Yeni kamu yönetimi: ülke deneyimleri (New public management: country experiences), Istanbul: Değişim Publications.

Altuntaş, N. (2007). Türkiye Reform Yönetimi (The Reform Management of Turkey), Basılmamış Yüksek Lisans Tezi (Unpublished Master Thesis), Ankara Üniversitesi Sosyal Bilimler Enstitüsü (Ankara University Social Sciences Institute).

Aslaner, A. (2006). Kamu idaresinde yeniden yapılanma çalışmaları (The reorganization efforts in public administration), pp.47-67, http://www.icisleri.gov.tr_ icisleri Türk Idare Dergisi>. (04.15.2015).

Ar, F. (1983). Türkiye'de ve Amerika birleşik devletleri'nde yapılan bazı idari reform çalışmaları (Some administrative reform efforts in Turkey and United States), Amme İdaresi Dergisi, Vol: 16, №: 3, pp.65-88.

Aykaç, B., Yaman, H. \&Özer, M. A. (2003). Türkiye'de idari reform hareketlerinin eleştirel bir tahlili (A critical analysis of administrative reform movements in Turkey), G.Ü. Íktisadi ve Idari Bilimler Fakültesi Dergisi, Vol: 5, No: 2, pp. 15-17. 
Aykaç, B. (2003). Yönetimin iyileştirilmesi ve örgütsel değişim (The improvement of administration and organizational change), (Eds.) B. Aykaç, Ş.Durgun, H.Yayman), Türkiye'de Kamu Yönetimi (Public Administration in Turkey), Ankara: Yargı Publications.

Coşkun, B. (2003). Kamu yönetiminde yeniden yapılanma: 1990'ı yıllardaki gelişmeler ve işkur örneğinin incelenmesi (The re-structuring at public administration: the developments in the 1990s and the examination of the işkur), Unpublished PhD Thesis, Ankara University Social Sciences Institute.

Coşkun, B. (2005). Türkiye'de kamu yönetiminde yeniden yapılanma tarihsel geçmiş ve genel bir değerlendirme (The re-structuring at public administration in Turkey, historical background and a general evaluation), Türk Idare Dergisi, No: 448, pp. 13-47.

Dinçer, N.\& Ersoy, T. (1974a). Merkezi hükümet teşkilatı araştırma projesi (MEHTAP) tavsiyelerinin uygulama durumunu değerlendirme araştırması (Assesment Research on the implementation of Mehtap recommendations), TODAIE Publication, Ankara.

Dinçer, N.\& Ersoy, T. (1974b). Kamu yönetimini yeniden düzenleme çalışmalarıyla ilgili bir değerlendirme (An assesment concerning the re-structing efforts of public administration), Amme Idaresi Dergisi, Vol: 7, No: 4, December 1974, pp. 73-92.

Demirci, A. G. (2010). Bir politika transferi örneği olarak Türkiye'de kadro sisteminin inşası (The construction of the cadre system in Turkey as a sample of policy transfer), Toplum ve Demokrasi, 4 (8-9-10), January-December, pp. 143-168.

DPT, Fifth five year development plan (1985-1989). DPT Publication, No: 1974, Ankara: 1985, http://ekutup.dpt.gov.tr/plan/plan5.pdf.

DPT, Sixth five year development plan (1990-1994). DPT Publication, Ankara-1989.

DPT, Seventh five year development plan (1996-2000). DPT Publication, Ankara.

DPT, Eight five year development plan (2001-2005). http://ekutup. dpt. gov. tr/ plan/ viii/ plan 8str.pdf.

DPT, Ninth five year development plan (2007-2013). http://pbk.tbmm. gov.tr/ dokumanlar/kalkinma-plani-9-genel-kurul.pdf.

Ergun, T. (1991). Yönetimin yeniden düzenlenmesi gereksinimi ve KAYA projesi (The necessity of reorganization of administration and KAYA Project), Amme Idaresi Dergisi (Tacettin Karaer'e Armağan), Vol: 24, No: 4, December-1991, pp.11-23.

Ergun, T. \&Polatoğlu, A. (1992). Kamu yönetimine giriş (Introduction to public adminstration), TODAIE, Ankara.

Ergun, T. (2004). Kamu yönetimi: kuram, siyasa, uygulama (Public administration: theory, policy-making, implementation), Ankara: Todaie Publication.

İdari Reform Danışma Kurulu Raporu (Administrative Reform Advisory Committee Report) (1972). İarenin yeniden düzenlenmesi: ilkeler ve öneriler (Administrative reorganization: principles and recommendations) (Ankara: Sevinç Publishing).

IGB (1994). 21.yya girerken Türkiye'de kamu yönetiminin geliştirilmesi ve bazı ülkelerdeki uygulamalar (The development of public administration at entering the $21^{\text {th }}$ century and practices in some countries), Ankara: İdareyi Geliştirme Başkanlığı (Administrative Development Directorate).

Geray, C. (1993). KAYA yazanağı açısından yönetimin taşra birimlerinin ve yerel yönetimlerin yeniden düzenlenmesi (Reorganization of provincial units of administration and local administrations in terms of KAYA). Çağdaş Yerel Yönetimler Dergisi, Vol: 2, No:1, January-1993, pp.9-17.

Gül, H. \& Aktel, M. (2004). Tarihsel bir bakış açısıyla kamu ve yerel yönetimler reformu (Public and local government reform with a historical perspective). Bigal Çanakkale: Yerel Yönetimler Kongresi (Local governments congress), Dünden Bugüne Yerel Yönetimlerde Yeniden Yapılanma Bildiriler Kitabı (Proceedings of re-structuring at local governments from the past to the present).

Güven, S. (1998). 1950'li yıllarda türk ekonomisi üzerinde amerikan kalkınma reçeteleri (American development prescriptions on Turkish economy in the 1950s), Bursa: Ezgi Publishing House.

Kalağan, G. (2010). Cumhuriyet dönemi Türk kamu bürokrasisi'nde yeniden yapılanma ve yönetsel reform çalışmaları (Re-structuring and administrative reform efforts at Turkish public bureaucracy at the republican period), Süleyman Demirel Üniversitesi Vizyoner Dergisi, Vol: 2, No: 1, pp.65-84.

Kalkınma Bakanlığı (Ministry of Development), (2014-2018). http://www.kalkinma.gov.tr/Lists/Kalknma\%20Planlar/Attachments/12/ Onuncu\%20Kalk\%C4\%B1nma\%20Plan\%C4\%B1.pdf.

Kantarcıoğlu, S. (1977). Devlet personel rejimi nasıldı? ne oldu? yeni düzenleme nasıl olmalıdır? (How did the state personel policy? What happened? How should be the new regulation?), Ankara: DPT Publications.

Kara, B. (2006). Türkiye'de personel reformu çalışmalarının alt yapısı: 1930-60 yılları arasında yabancı uzmanların kamu yönetimine ilişkin hazırladıkları raporlar (The background of the personel reform efforts in Turkey: the reports prepared by the foreign experts from 1930 to 1960), Cumhuriyet Üniversitesi Sosyal Bilimler Dergisi, Vol: 30, No:2, pp. 149-162.

Karaer, T. (1987a). Kamu yönetimini yeniden düzenlenme girişimleri ve sonuçları üzerine bir deneme (An essay on the re-structuring initiatives and results of public administration), Amme İdaresi Dergisi, Vol: 20, No:2, pp.25-46.

Karaer, T. (1987b). 12 Eylül ve Türk kamuoyunun yeniden düzenlenmesi (September 12 and re-organization of Turkish public opinion), Amme Idare Dergisi, Vol: 20, No: 3, pp. 29-54.

Karaer, T. (1991). Kalkınma planları ve idari reform (Development plans and administrative reform), Amme Idaresi Dergisi, Vol: 24, No:2, pp.43-65.

Keleş, R. (2006). Yerinden yönetim ve siyaset (Decentralization and politics), 5. Edition, Istanbul: Cem Publishing House.

Mehtap Yönetim Kurulu Raporu (Mehtap Board Report), (1966). Merkezi hükümet teşkilatı kuruluş ve görevleri (The organization and functions of central government organization), 2. Edition, TODAIE Publication, Ankara.

Mıhçıoğlu, C. (2003). Kamu yönetiminde verimlilik (Efficiency in public administration), (Eds.) B. Aykaç, Ş. Durgun and H. Yayman. Türkiye'de Kamu Yönetimi (Public Administration in Turkey), Ankara: Yargı Publishing House.

Sevinç, H. (2014). Değişim ve kurumsal yapılandırma süreci: merkezi hükümet teşkilatı araştırma projesi (MEHTAP) (Change and institutional configuration process: central government organization research project), Uluslararası Sosyal Araştırmalar Dergisi, 
Vol: 7, No: 35, pp.730-747.

Sözen, S. (2002). Administrative reforms in Turkey: imperatives, efforts and constraints, Ankara Üniversitesi SBF Dergisi, Vol: 60, No:3, 2005. pp.196-214.

Sürgit, T. (1968). Merkezi hükümet teşkilatı araştırma projesi mehtap yönetim kurulu raporu ve uygulanışı (MEHTAP board report and its implementation), Amme Idaresi Dergisi, Vol: 1, No: 2, pp. 1-10.

Sürgit, K. (1972). Türkiye'de idari reform (Administrative reform in Turkey), TODAIE Publication, Ankara.

Sürgit, K. (1980). 12 Eylül ve yönetimin yeniden düzenlenmesi (12 September and re-organization of administration), Amme Idaresi Dergisi, Vol: 20, No: 3, pp.29-54.

Şaylan, G. (1973a). Üçüncü beş yillık plan ve idari reform (Third five year development plan and administrative reform), Amme İdaresi Dergisi, Vol: 6, No: 2, pp.15-28.

Şaylan, G. (1973b), Bir yapısal değişim sorunu olarak yönetim reformu (Administrative reform as a structural change problem), Prof. Dr. K.F.Ark'a Armağan, SBF-TODAIE Publication, Ankara.

Şaylan, G. (2000). Kamu personel yönetiminden insan kaynakları yönetimine geçiş (The transition from public personel administration to human resource management), Istanbul: TESEV.

Şaylan, G. (2003). Bir yapısal değişim sorunu olarak yönetim reformu (Administrative reform as a structural change problem), (Eds.) Burhan Aykaç, Şenol Durgun, Hüseyin Yayman, 1. Edition, Türkiye' de Kamu Yönetimi (Public administration in Turkey), Ankara: Nobel Publishing.

Şaylan, G. (2012). Bir yapısal değişim sorunu olarak yönetim reformu Administrative reform as a structural change problem)., (Eds.) Burhan Aykaç, Şenol Durgun, Hüseyin Yayman, 2. Baskı, Türkiye' de Kamu Yönetimi, Ankara: Nobel Publishing.

Tatar, T. (2006). Türk kamu yönetiminde idari reformlar bağlamında reform yönetimi (Reform management in the context of administrative reforms at Turkish public administration), Master Thesis, Ankara University Social Sciences Institute.

Todaie (1965). İdari reform ve reorganizasyon hakkında ön rapor (The preliminary report on administrtative reform and reorganization), Ankara: Kardeş Publishing.

Todaie (1972). Idarenin yeniden düzenlenmesi öneriler ve ilkeler (Re-organization of administration recommendations and principles), İdari Reform Danışma Kurulu Raporu (Administrative reform advisory board report). Ankara: TODAIE Publication No: 123.

Todaie (1991). Kamu yönetimi araştırması genel rapor (General report of public administration research), Ankara: TODAIE Publication.

Tortop, N., İ̧̧bir, E. G., Aykaç, B. (1993). Yönetim Bilimi (Administrative science), Ankara: Yargı Publishing.

Tutum, C. (1994). Kamu yönetiminde yeniden yapılanma (Re-structuring at public administration), Ankara: TESAV Publications.

Tutum, C. (2012), Kamu yönetiminde yeniden yapılanma (Re-structuring at public administration), (Eds.) Burhan Aykaç, Şenol Durgun, Hüseyin Yayman, Türkiye' de Kamu Yönetimi (Public administration in Turkey), Ankara: Nobel Publishing.

Uçar, M. \& A. Karakaya (2014). Yönetsel reformlar perspektifinden Türkiye'de yönetimin gelişimi üzerine bir inceleme (A review on development of administration in Turkey from the administrative reforms perspective), Karabük Üniversitesi Sosyal Bilimler Enstitüsü Dergisi, Vol: 4, No: 2, pp.152-169.

Yalçındağ, S. (1971). Devlet kesimini yeniden düzenleme çalışmalarının amacı ve stratejisi üzerine (On the purpose and the strategy of the re-organization efforts of government section), Amme Idaresi Dergisi, Vol: 4, No: 2, pp. 24-31.

Yaşamış, F. (2001). Osmanlı devlet yönetiminin başlangıç yılları (The early years of Ottoman state administration), Türk Idare Dergisi, S. 432, Eylül 2001, pp.1-32. 